\title{
Review
}

\section{Towards an improved understanding of greenhouse gas emissions and fluxes in tropical peatlands of Southeast Asia}

\author{
Prashant Kumar,", Adedeji A. Adelodun', Md Firoz Khanc, Haruni Krisnawatid, \\ Fernando Garcia-Menendez ${ }^{\mathrm{e}}$ \\ ${ }^{a}$ Global Centre for Clean Air Research, Department of Civil and Environmental \\ Engineering, Faculty of Engineering and Physical Sciences (FEPS), University of Surrey, \\ Guildford GU2 7XH, United Kingdom \\ ${ }^{b}$ Department of Marine Science and Technology, School of Earth and Mineral Sciences, \\ The Federal University of Technology, P.M.B. 704, Akure, Nigeria \\ ${ }^{c}$ Department of Chemistry, Faculty of Science, University of Malaya, 50603 Kuala \\ Lumpur, Malaysia \\ ${ }^{d}$ Forestry and Environment Research, Development and Innovation Agency, Jl. Gunung \\ Batu No 5 Bogor, Indonesia \\ ${ }^{e}$ Department of Civil, Construction and Environmental Engineering, North Carolina State \\ University, Campus Box 7908, USA
}

\begin{abstract}
At present, there is insufficient data to understand the processes driving emissions and fluxes of greenhouse gases (GHGs) from tropical peatlands in Southeast Asia (SEA). In this review, we discuss fundamental factors controlling emissions of major $\mathrm{GHGs}\left(\mathrm{CO}_{2}, \mathrm{CH}_{4}\right.$, and $\left.\mathrm{N}_{2} \mathrm{O}\right)$ from tropical peatlands and their contribution to global climate change. Classifying peatlands in tropical and subtropical regions can aid in understanding their emission characteristics. The applicability of existing GHG emission factors to land use categories in SEA is discussed. We find that rewetting peatland can increase $\mathrm{CH}_{4}$ emissions, and therefore more studies are needed to establish whether peatlands act as a net sink or net sources of GHGs. Few studies have investigated the effectiveness of liming toward reducing peat soil acidity. The review also finds that there is limited data on $\mathrm{CO}_{2}$ concentrations in drainage and wildfire areas, $\mathrm{N}_{2} \mathrm{O}$ fluxes in agriculture areas, and the impact and reduction of $\mathrm{CH}_{4}$ in tropical peatlands. Addressing these research gaps could support the development of a framework for GHG emission measurements and abatement in tropical peatlands.
\end{abstract}

Keywords: Peat soil; Water management system; Greenhouse gases; Emission fluxes; Global Climate Change

\section{Research highlights}

- GHG emissions from peatlands and their contributions towards global climate are assessed.

- Southeast Asia is a significant region for peatlands; their restoration can reduce GHG emissions.

- $\mathrm{CO}_{2}$ and $\mathrm{N}_{2} \mathrm{O}$ emission fluxes from drainage, fire and agriculture areas are insufficiently known.

- Very little is known on drained peatlands and their GHG emission characterisation is required.

- Modern technology with traditional knowledge is important for peatland water management.

\footnotetext{
* Corresponding author: Email: P.Kumar@ surrey.ac.uk; Tel.: +44 (0)1483 682762
} 


\section{Introduction}

Climate change is a global issue that has been identified as a pressing concern over the past 30 years. Continuous emissions of GHGs (e.g., $\mathrm{CO}_{2}, \mathrm{~N}_{2} \mathrm{O}$ and $\mathrm{CH}_{4}$ ) have been linked to several environmental problems, including global temperature rise, alterations in precipitation patterns, changes in groundwater levels and soil conditions, and extreme weather events (Kumar and Imam, 2013; Isaksen et al., 2009). Therefore, researchers have been working to identify different sources of GHG emissions and develop strategies to mitigate them. Peatlands, however, are a key source of GHGs that remains poorly understood.

Peatland refers to land dominated by peats, formed from partially carbonised vegetable matter under waterlogged conditions (Worrall et al., 2010). As shown in Figure 1, the accumulation and decomposition of organic materials in unbalanced, low temperature, anoxic, anaerobic, and low-decomposability conditions favor the formation of peats (Rydin and Jeglum, 2013; Zinck et al., 2011; Couwenberg, 2009). Common stock materials for peat formation include woods, leaves, roots, and rhizomes. Mostly, peats are deposited photosynthetic matter that is buried under additional layers of litter, thereby creating the conditions for peat formation (Rydin and Jeglum, 2013).

Depending on region and history, the thickness of peatlands can vary between 30 and 70 $\mathrm{cm}$, (Josten and Clarke, 2002). For example, the minimum thickness is $30 \mathrm{~cm}$ in England and Wales, $40 \mathrm{~cm}$ in Canada (Rydin and Jeglum, 2013), and $50 \mathrm{~cm}$ in Scotland (Holden et al., 2004; Johnson, 1963). Peats are examples of the soil type Histosol (Wösten et al., 2008; FAO-UNESCO, 1990). Histosols have a surface layer characterized by a minimum of $30 \%$ organic matter. Thus, their degree of humification is also influenced by hydraulic conductivity, water retention, nutrient availability, and load-bearing capacity.

Peatlands can be found in areas with various temperature levels, ranging from cool, temperate boreal regions to tropical or subtropical regions (Zinck et al., 2011). The boundaries between tropical-subtropical peats and temperate-boreal peats include Southeast Asia (SEA), Africa, Florida, North Carolina, Southern Brazil, and Uruguay (Zinck et al., 2011). These different peatlands can be distinguished by relevant form. For example, intertropical lowland peat has surplus rainfall and high temperature. Peat oxidation is accelerated by high temperatures, with little diurnal and seasonal variations. Peatland hydrology, controlled by rainfall, has an impact on vegetation type and composition. Peatlands in tropical lowland forests are commonly covered by peat swamps, unlike in temperate peatlands which are generally covered by sedges and moss. In the subtropical areas at mid-latitudes, the characteristic rainfall is important to peat formation, but annual temperature variations are more significant (Zinck et al., 2011). Page et al. (2011) reported an estimated tropical peatland area of $439,238 \mathrm{~km}^{2}(\approx 11 \%$ of global peatland area), of which $247,778 \mathrm{~km}^{2}(57 \%)$ is in (SEA). 
Tropical peatlands in forests serve as one of the most efficient carbon sinks and are one of the largest near-surface reserves for terrestrial organic carbon (Marwanto and Agus, 2014; Anshari et al., 2004). In tropical peatlands, approximately 16.5 to $68.5 \mathrm{Gt}$ of carbon is stored in a land area ranging from 275,400 to $570,600 \mathrm{~km}^{2}$, with a thickness between $1-2 \mathrm{~m}$ and approximate carbon density of $60 \mathrm{~kg} \mathrm{~m}^{-3}$ (Zinck et al., 2011). When in a stable chemical form, peatlands store a large quantity of carbon which, upon degradation, can be released into the ecosystem as $\mathrm{CO}_{2}$ and $\mathrm{CH}_{4}$ (Page et al., 2002; IPCC, 2001). Their stability can be threatened by activities (such as the drainage and forest clearing) which render the land firesusceptible (Page et al., 2002).

Peatlands are of interest due to their unique characteristics, including their $\mathrm{CH}_{4}$ emissions. Peatlands are believed to contribute about $15 \%$ to $20 \%$ of global $\mathrm{CH}_{4}$ emissions (Fan et al., 2014), which given the high warming potential of $\mathrm{CH}_{4}$ suggest a significant impact on global climate (Fan et al., 2014; Worrall et al., 2010; Forster et al., 2007). Peatlands stability is directly related to GHG emissions potential (Sukarman et al., 2012). Losing carbon in peatlands via forest fire and land clearing accounts for about 4.5 and $7.9 \mathrm{t} \mathrm{C} \mathrm{ha}^{-1} \mathrm{y}^{-1}$, respectively (Hooijer et al., 2014).

Fires in peatland are one of the most important environmental problems in SEA, especially in Indonesia, Singapore, Malaysia, Brunei, and southern Thailand (Nagano et al., 2013, Suzuki et al., 1999). Drainage and clearing on peatlands over recent years have resulted in an unprecedented increase in peat fires. For example, Kalimantan and Sumatra (in Indonesia) have experienced severe fire outrage over the years. GHGs and other toxic pollutants (e.g., CO, VOCs and PAHs) are emitted from the burning of peat soil, which can also endanger critical ecological systems (Jayaretney et al. 2017, Huijnen et al. 2016, Stockwell et al. 2016, Yokelson et al. 1997). These events can significantly impact human health. For instance, due to haze caused by peatland fires in 2015, about 100,300 excess deaths were reported over Indonesia, Singapore, Malaysia, and Brunei (Koplitz et al. 2016). The related average inpatient health impact in Malaysia for 2005, 2006, 2008 and 2009 was valued at MYR 273,000 (US \$91,000) (Othman et al. 2014). In another example, wildfires affected Indonesia's island of Sumatra in June 2013 and triggered a severe air pollution episode in Singapore with daily $\mathrm{PM}_{2.5}$ concentration reaching $310 \mu \mathrm{g} \mathrm{m}^{-3}$ (Velasco and Rastan, 2015).

Experimental and numerical approaches have been used to investigate the role of peatlands in global climate and their GHG emissions. In 1997, between 0.87 and $2.57 \mathrm{Gt}$ C (3-10 Gt $\mathrm{CO}_{2}$ (Nusantara et al., 2014) was emitted from forest fires (Page et al., 2009; Page et al., 2002; Page et al., 1999). Annually, about 2-3 Gt $\mathrm{CO}_{2}$ eq of $\mathrm{CO}_{2}$ and $\mathrm{N}_{2} \mathrm{O}$ are emitted from drained peatlands (Joosten and Couwenberg, 2009). Based on data collected by prior studies the role of peatlands in GHG budgets has been summarized as follows: (1) peatlands store carbon in their tissues in organic form; (2) when decomposed anaerobically, they release 
$\mathrm{CH}_{4}$ from the reduction of $\mathrm{CO}_{2}$ (Setyanto et al., 2014); (3) via photosynthesis, peatlands sequester carbon as $\mathrm{CO}_{2}$ during peat formation (Marsden and Ebmeier, 2012).

We consider these descriptions of the influence of peatlands on GHG budgets to be limited and incomplete. Beyond these simplified characterizations, tropical conditions, agricultural activities, land management, and drainage systems impact peatland GHG emissions in SEA. Therefore, we present a comprehensive review on the physical and chemical nature of tropical peatlands in SEA (specifically those in Peninsular Malaysia, Sumatra, Borneo and Papua), including their ecological features and the drivers and magnitude of associated GHG emissions within the region. Additionally, we identify emissions mitigation approaches for SEA peatland areas, particularly focused on the agricultural sector.

\section{Peatland distribution in SEA}

Globally, peatland area is estimated to be $4.26 \mathrm{M} \mathrm{km}^{2}$, accounting for approximately 3\% of total land mass (Zinck et al., 2011; Chimner and Karberg, 2008; Chimner and Ewel, 2005; Andriesse, 1988; Mona, 1984) and capable of storing carbon at 3,000 $\mathrm{t} \mathrm{ha}^{-1}$ (Setyanto et al., 2014; Gorham et al., 2012), equivalent to $20 \%$ the world's carbon stocks. Global peatland distribution is shown in Figure 2a and the distribution in SEA is depicted in Figure 2b. Within the global peatland area, tropical peatlands cover about 45 Mha (12\%) (Wösten et al., 2008; Page et al., 1999). Together, Indonesia ( $\approx 35 \%$ of global, i.e. 22 Mha), Malaysia, and Vietnam account for approximately $70 \%$ of tropical peatlands. Page et al. (1999) documented that Papua, Borneo, and Sumatra, three islands in Indonesia, cover 4.6, 6.8, and 8.3 Mha peatlands, respectively. Hooijer et al. (2010) reported that SEA has a lowland peatland landmass of about 27.1 Mha, out of which 22.5 Mha are in Indonesia. Central Kalimantan, for example, has an area of $153,564 \mathrm{~km}^{2}$, consisting of $17.3 \%$ peatland ( 2,651,724 ha) (Limin et al., 2007). Major peat areas in Peninsular Malaysia, Sumatra, Borneo and Papua are highlighted in Figure 3.

Unger (2012) and van Noordwijk et al. (2014), report that land use emissions in SEA account for $14 \%$ of global GHG emissions. Being the largest contributor in SEA, Indonesia could lead to the reduction of GHG emissions from land uses, although, there are still uncertainties about the relationship between GHG emissions to biomass burning and land cover change. Still, peatland restoration can be an important strategy to reduce of GHG emissions. One restoration approach is rewetting. However, peatland rewetting has been reported to cause $\mathrm{CH}_{4}$ emissions, a drawback which needs to be addressed (Couwenberg, 2009). This review aims to comprehensively describe GHG emissions from SEA peatlands, as well as activities that can drive or mitigate their contribution to global warming.

\section{Classification of peatlands}

Based on the geographical location and tide movement, peatlands are broadly classified into two categories: (i) inland peat, which is uninfluenced by sea water, and (ii) coastal peat, which is generally influenced by sea water (Bourgeau-Chavez et al., 2018; 
Anderson, 1983). Table 1 summaries the classification of peatlands based on some natural characteristics. According to Hooijer et al. (2010), there are insufficient data about peat thickness in some places where some content of domes lay deeper underneath sampled shallow peat. Moreover, subsoil beneath the inland peat (usually quartz, sand, and granite) lowers the soil nutrient significantly. On the other hand, coastal peatlands have a thickness range of $25-100 \mathrm{~cm}$. As a result of seawater sedimentation, they produce some nutrients that improve soil fertility. At maturity, the inland peatlands are either hemic or sapric. However, because the subsoil is predominately marine, high acidity $(\mathrm{pH}<4.0)$ ensues. Peatlands are also classified into fibric or hemic based on their decomposition and vegetative growth.

With respect to the source and nutrient types, peatlands can be classified as bogs (ombrotrophic) and fens (minerotrophic) (Worrall et al., 2010). Bogs are further subclassified into blanket and raised bogs (Worrall et al., 2010; Lindsay, 1995), while fens are sub-classified into four: basin, valley, floodplains, and sloping fens (Charman, 2002). Another kind of classification based on the level of fertility, ash content, and content of $\mathrm{P}_{2} \mathrm{O}_{5}, \mathrm{CaO}, \mathrm{K}_{2} \mathrm{O}$ was made by Polak (1949). This classification categorized peat into three types: eutrophic peat (with high fertility level), mesotrofik peat (with moderate fertility level), and oligotrofik peat (with low fertility level). Most peat soils are low in both macro and micronutrients (Hartatik et al., 2011). Peats formed near the coast, generally topogen peat, are more fertile than inland peat (i.e., ombrogen). Several factors responsible for peatlands' fertility include soil layer thickness, the composition of the parent peat plant, degree of decomposition, and minerals under the peat layer. So far, those are the available classifications of peatlands; they are detailed to improve their understanding, which in turn, could initiate further studies.

\section{Properties of peatland soil}

\subsection{Physical properties}

Pandjaitan and Hardjoamidjojo (2008) reported that the physical properties of peatlands are important, especially for their reclamation and water management, soil mechanics, soil engineering, and peat conservation. This section provides information on the important physical properties of peat deemed highly significant (Andriesse,1988).

\subsubsection{Water retention and water availability}

Peats are highly hydrophilic; they can absorb water up to 13 times their dry weight (Hartatik et al., 2011). However, it was earlier reported that in saturated conditions, peatlands exhibit water retention between $4.5 \%$ and $30 \%$ of their dry weight (Andriesse,1988). Table 2 shows their water content at different decomposition level. Such information on water availability is important to the agriculture sector. Also, the adequate information on the differences between mineral soil and organic soil are relevant to the water retention of peatlands. For example, (i) the volume soil solidity in organic soil is lower than in mineral soil; and (ii) at low pressure, organic soil has higher water retention than organic soil (Andriesse, 1988). 


\subsubsection{Hydraulic conductivity and water holding capacity}

According to Andriesse (1988), knowledge about the hydraulic conductivity of peatlands to predict water flow behavior in the soil is important. Horizontally, the hydraulic conductivity is very fast but very slow in vertical flow, the latter is due to groundwater obstruction to vertical water flow (Pandjaitan and Hardjoamidjojo, 2008). Moreover, the water holding capacity in peatlands also depends on the level of decomposition (Table 2), which is the highest in fibric peatlands (Pandjaitan and Hardjoamidjojo, 2008). Furthermore, hydraulic conductivity is faster in fibric peatlands than in sapric peatlands, because of lower peatland porosity in the latter (Andriesse, 1988).

\subsubsection{Bulk density $(B D)$ and porosity}

Because of high water content, peats have a low BD, rendering them flabby (i.e., having low tensile strength) (Widjaja-Adhi, 1988). Depending on the level of decomposition, the $\mathrm{BD}$ of topsoil peats varies between 0.1 and $0.2 \mathrm{~g} . \mathrm{cm}^{-3}$. However, fibric peats (usually located in the bottom soil layer) have BD less than $0.1 \mathrm{~g} . \mathrm{cm}^{-3}$, whereas due to the presence of the mineral soil, coastal peats and peats along river flow have BD less than 0.2 g.cm $\mathrm{cm}^{-3}$ (Hartatik et al., 2011). According to Widjaja-Adhi (1988), low BD peat causes low resistance-bearing capacity, making operations on the soft soil difficult for mechanical equipment. In addition, the porosity of peatlands influences the flow of groundwater proportionately, with fibric peat (having big pores) often exhibit high groundwater flow (Andriesse, 1988).

\subsubsection{Irreversible drying characteristics}

Upon exposure to heat, peats undergo irreversible drying, i.e., dried peats are unable to reabsorb water when wetted, becoming permanently hydrophobic. Also, peat shrinks significantly when drained (compaction by contraction). In addition to peat compaction, subsidence also occurs due to decomposition and erosion. In the first two years after peat drainage, subsidence rate may reach $50 \mathrm{~cm} . \mathrm{yr}^{-1}$. A year afterwards, the subsidence range from 2 to $6 \mathrm{~cm} \cdot \mathrm{yr}^{-1}$, depending on the maturity and depth of peat drainage channels (Hartatik et al., 2011). Figure 4 illustrates the effect of continued drainage on peatlands.

Dry peats are easily eroded by water flow in wet conditions, and are highly flammable in a dry environment. When burning, peats produce higher thermal energy than wood or charcoal. Although, a burning mass of peat is difficult to control because the fire may spread under the surface, leading to a forest wildfire (Hartatik et al., 2011).

\subsection{Chemical properties}

The chemical content of tropical peatlands is predominantly associated with the percentage of organic carbon, which ranges from 35\% to 60\% (Melling and Henson, 2011). Further, Melling et al. (2013) observed that the total carbon in peat soil is between 52.3\% and $58.2 \%$, with the depth of $0-50 \mathrm{~cm}$, whereas the ratio of $\mathrm{C}$ to $\mathrm{N}$ is approximately 28.2:41.6. The $\mathrm{pH}$ was found in a close range of 3.5 to 3.7. The chemical properties that 
influence the availability of peat nutrients are divided into three categories: (i) eutrophic, (ii) mesotrophic, and (iii) oligotrophic (Table 3). They are based solely on the water source and water quality, and not determined by any property of the peat (Zinck et al., 2011). Chemical properties such as $\mathrm{pH}$, ash content, contents of nitrogen $(\mathrm{N})$, phosphorus $(\mathrm{P})$, potassium $(\mathrm{K})$, base saturation, and micronutrients are significant to the nourishment of peat plants (Hartatik et al., 2011). For example, some reported chemical properties of peatlands in Indonesia are summarized in Table 4.

Peat's organic matters have reactive, but weak acid groups (carboxylic and phenolic acids) that contribute about $85-95 \%$ of peat soil acidity. The acidity tends to decline with depth. Liming peat soil to increase its $\mathrm{pH}$ is ineffective because the aluminum content of peat is low. Generally, coastal peatlands are less acidic than inland peatlands due to the enrichment of tide-derived bases (Hartatik et al., 2011). The anaerobic decomposition of woody peat soils and rich lignin produces aliphatic acids and phenolic acids (Hartatik et al., 2011; Kononova, 1968). Most of these acids are poison for plants. Some of the phenolic acids commonly found in soil are vanilat acid, p-kumarat, p-hydroxybenzoic, salicylic, galat, sinapat, and syringat acid. Hartatik et al. (2011) have shown that phenolic acids are phytotoxic to plants and cause stunted plant growth by inhibiting the provision of nutrients in the soil.

Oliogotrophic peatlands (as found in Borneo) have a very low content of base cations (such as $\mathrm{Ca}, \mathrm{Mg}, \mathrm{K}$, and $\mathrm{Na}$ ). Lower base metal concentrations (i.e. higher soil acidity) are characteristic of thicker peats (Hartatik et al., 2011). The Cation exchange capacity (CEC) of peat soil is generally high (range of $90-200 \mathrm{cmol} . \mathrm{kg}^{-1}$ ). This is largely due to the presence of carboxyl and phenolic groups, which are $\mathrm{pH}$ dependent. Therefore, the CEC increases with pH (Hartatik et al., 2011). The negatively charged site on peats is formed by the dissociation of the hydroxyl group. Naturally, peat soils have low fertility because of the large amount of toxic organic acids which inhibit most nutrients. To reduce the effects of the acids, polyvalent cations ( such as $\mathrm{Fe}^{2+}, \mathrm{Al}^{3+}$ ), $\mathrm{Cu}^{2+}$, and $\mathrm{Zn}^{2+}$ could be added to the peat. These cations complex with the organic sites, thereby ameliorating the peat (Hartatik et al., 2011). Due to a large number of polyvalent metal ions required, the effectiveness of liming (addition of $\mathrm{Mg}^{2+}$ and $\mathrm{Ca}^{2+}$ ) peat soil to elevate its $\mathrm{pH}$ needs to be studied further.

In addition, there is a need to study, in details, the $\mathrm{C}$ and $\mathrm{N}$ cycles in tropical peatlands, due to finite data currently available about them. Such a study is essential because the available emission factors have an unclear relationship between the land use categories in SEA. Previous studies have shown that the $\mathrm{C}: \mathrm{N}$ of peat soil is relatively high, and it increases with the depth. Usually, the total amino-based $\mathrm{N}$ content is relatively high. However, the availability of $\mathrm{N}$ for plant nutrition in peat soil is generally low. Therefore, to provide optimum $\mathrm{N}$ for plants, $\mathrm{N}$ fertilization is required (Hartatik et al., 2011). The microelement content of bottom peat soil is generally lower than at the top layer. However, the reverse could ensue if the bottom layer is mixed with mineral soil materials (Hartatik et al., 2011). 
The microelement content can be increased by the addition of minerals or fertilizer. On peatlands, microelements (such as $\mathrm{Cu}$ ) are usually unavailable to plants because they are absorbed strongly by peat soil.

\section{Peatland ecosystem}

Figure 5 provides an overview of peatland ecosystem services as influenced by both natural and anthropogenic activities, including climate change. Because of its capacity to store carbon, swamp forest is important to peatland ecosystem. Also, the tropical peat swamp forest is an important contributor to regional and global biodiversity (Wösten et al., 2008; Andriesse, 1988). In natural conditions, tropical peatlands serve as reservoirs for freshwater, maintain water level, reduce storm-flow, sustain the river flows, and prevent saltwater intrusion (Wösten et al., 2008). As a unique ecosystem, tropical peat swamp forest is a habitat for some rare or threatened species of aves, pisces, mammals, and reptiles (Wösten et al., 2008; Ismail et al., 1999). Moreover, Marsden and Ebmeier (2012) found that peatlands are important habitat for species with particular affinity for acidic, lownutrient, and waterlogged conditions. Vegetation in peatland is responsible for the unrecognized changes in both the water level and water chemistry of their environment (Holden et al., 2004). Furthermore, ecological knowledge of response to vegetation after a fire incident is important to determining the actions related to planning for restoring or converting the area for efficient land use; the tropical secondary vegetation, being a carbon sink, is a potential regulator of climate change, (Hoscilo et al., 2008; Lucas et al., 2006; Castro et al., 2003).

In the last decade, tropical peatlands have been in steady condition, even though the peatland is negatively impacted by climate and land use (Wösten et al., 2008). Over $25 \%$ of peatlands (usually tropical peat swamp forest) are degraded by fire, drainage, logging, and land conversion (Page et al., 2008). For example, approximately 30 Mha (25\%) of the Indonesian forest were lost in the past 15 years. In comparison to ecology and hydrology, fire and flooding are the most important ecological barriers in forest restoration. They could significantly hinder some important ecological phenomena such as pest control, pollination, water infiltration, etc. (Norowi et al., 2008). Developing peatlands while ensuring the sustainability of the ecosystem therein is challenging. Drainage (be it natural or artificial) and addition of fertilisers for the improvement of peatland's $\mathrm{pH}$ and nutrient levels are partly responsible for ecological restoration difficulties (Holden et al., 2004; Bragg and Tallis, 2001). If canal construction has caused some impairment on the peat layer, such significant change in the ecosystem will cause increased decomposition of peat, followed by the release of $\mathrm{CO}_{2}$.

\section{Hydrology and water management in peatlands}

Hydrology is an important factor in keeping peatlands in a stable condition. In peat swamps ecosystem, hydrology depends on climate, topography, natural subsoil, and drainage base (Ritzema, 2008). Peatland hydrology is controlled by rainfall, which impacts 
both vegetation type and composition (Zinck et al., 2011). With about 10\% of global freshwater in the peatlands, it is important to maintain the water quality in the highland catchment areas (Marsden and Ebmeier, 2012; Josten and Clarke, 2002). For instance, in the 1960s, lowland development for rice cultivation was inspired by adopting traditional techniques combined with emerging engineering approach for systematic soil improvement in Indonesia. The result was remarkable: food crops (such as rice, corn, soybean, peanut, vegetables) and perennial crops (such as fruit trees, coconut, coffee and cloves) flourished (Rieley et al., 2008). Based on this development, similar projects were carried out at Sumatera, Kalimantan, and Papua. In 1996, one of such projects was the Mega Rice Project (MRP) in Central Kalimantan, with a total land area of 1,457,100 ha (Rieley et al., 2008). Varied dimensions of channels were constructed across the peatland landscape and completed in three years. According to Limin et al. (2007), the total length of the canals was 4,473.46 km, including main primary canals $(187 \mathrm{~km})$, primary canals $(958.18 \mathrm{~km})$, secondary canals $(913.28 \mathrm{~km})$, tertiary canals $(900 \mathrm{~km})$, and quaternary canals $(1,515 \mathrm{~km})$. However, the problem of insufficient water from the upper stream of three big rivers (Kahayan, Kapuas and Barito) has rendered the irrigation ineffective for the intended purpose (i.e., to create routes for transporting log out of the forest) (Rieley et al., 2008). Blocking canals is one of the solutions to recover hydrological status in peatland areas (Limin et al., 2007).

Due to the impact of the drainage system, the water content of peat soil depletes sharply, thereby affecting the temperature and humidity of the upper layer. In fact, in a year, the soil surface subsidence reaches between 1.0 and $3.0 \mathrm{~cm}$, as influenced by hydrological conditions of the area. The peatland further subsidies when it is over-drained with excavated giant canals in the area of MRP, constructed across the deepest peat area (i.e., peat dome) with thickness $\geq 3 \mathrm{~m}$ (Limin et al., 2007). Sometimes, without peat management sustainability systems (as used by Dayak people, such as the handel and anjir), the thickness could reach up to 8 or $10 \mathrm{~m}$. Usually, the extreme environmental impacts are drought and flooding. Despite the information collected, there are limited data on peatland drainage for other countries in SEA. Therefore, additional research is needed as the water level continues to decrease in unused peatlands, and groundwater depths increases due to land use (Hooijer et al., 2010).

\section{Land use and land-use change in peatland}

Since the 1970s, tropical peatlands have been developed especially in the SEA, a region which dominates the coastal peatland for small-scale agriculture. However, ever since the 1990s when agricultural activities rose sharply, the peatlands have enlarged further into the inland (Rieley et al., 2008). More than 25 years ago, scientists from Indonesia and the Netherlands identified principal problems associated with tropical peatland reclamation. Such problems include chemical impoverishment, peat acidity, and extremely low ash content. As Rieley et al. (2008) opinionated about peat soils, "No other soil type combines so many unused possibilities with so many unsolved difficulties... A multidisciplinary effort 
is needed to find ways to exploit the potentially suitable for peat formations in a nondestructing way". For example, peatland use for agricultural purposes in Central Kalimantan was unsuccessful. The failure was attributed to the carrying capacity, land ecosystem, culture, local wisdom, and crops market. Limin et al. (2007) inferred that the potentials of peatlands are not about thickness only, but also based on the underlay natural materials, the hydrology status, knowledge of peatland cultivation, culture of the community, and marketability of products from peatlands. In contrast, MRP policy has no consideration for the local people, who have first-hand and grounded knowledge about water management of the area, especially for successful rice cultivation.

For agricultural practices, Dayak people use shallow peat only because it is richer in nutrient rather than inland peat (UNEP/GEF, 2008). Shallow peats in upstream have the following characteristics: (1) peat thickness is between 20 and $50 \mathrm{~cm}$; (2) decomposition condition is hemic to sapric; (3) bottom material is clay; (4) location is near river banks or between hills; (5) previous vegetation is dominated by grass; (6) water supply is from rainfall and river flood; and (7) soil becomes muddy after planting. Whereas, the characteristics of coastal areas used by the Dayak people are: (1) they are influenced by sea tidal movement, flooding the rice field incessantly; (2) location reaches about $2 \mathrm{~km}$ from the river bank; (3) maximum peat thickness ranges from 1.0 to $2.0 \mathrm{~m}$; (4) clay is the underlay material; (5) decomposition status is mostly sapric; (6) nutrients are provided by tidal movement twice a day; and (7) the soil becomes muddy after planting.

Rice cultivation would flourish in the peatlands provided the land is irrigated by the fluctuation at river level. The rice cultivation of inland peat with peat thickness less than $100 \mathrm{~cm}$ introduces some constraints to the growth and yield of the rice. Lest, if the underlay material is sand or granite, the yield depreciates further. However, crops that grow in deep peat would exhibit low yield and shorter production periods. Such conditions can be improved by high lime input and fertilizers (Limin et al., 2007). Thence, standardized methods for the survey and evaluation of peatlands is needed, because each country has its own definitive philosophy about land use (Hooijer et al., 2010). Moreover, more study on tropical peatland water systems is needed.

\section{Influence of emissions on peatlands}

One of the areas of research interest on tropical peatlands is the emissions associated with the land type. Figure 6 provides the annual $\mathrm{CO}_{2}$ emission values, categorized based on emission source (due to land use change and peat decomposition) in Indonesia and Malaysia, as reported by Agus et al. (2013). The $\mathrm{CO}_{2}$ concentration values attributed to land use change and the oxidation of peat soils from drainage and conversion were also compared. Some peatlands in SEA have been deforested either through burning or conversion for oil palm and pulpwood plantation purposes. This situation has affected the net GHG balance of peatlands by some flux components: (1) net $\mathrm{CO}_{2}$ uptake by vegetation, (2) $\mathrm{CO}_{2}$ emissions from drainage-related peat decomposition, (3) huge $\mathrm{CO}_{2}$ emissions from fires, (4) exports 
of dissolved and particulate organic carbon, and (5) small-quantity emissions of $\mathrm{CH}_{4}$ and, possibly, $\mathrm{N}_{2} \mathrm{O}$. Agriculture, as a potential source of $\mathrm{GHG}$ emissions in peatlands has been established, so also are the interrelationships among $\mathrm{CH}_{4}, \mathrm{~N}_{2} \mathrm{O}, \mathrm{NH}_{3}$ and $\mathrm{NO}_{\mathrm{x}}$ from the practice (Gurjar et al., 2015; Brink et al., 2005) .

\subsection{Carbon dioxide $\left(\mathrm{CO}_{2}\right)$ emissions}

Among all GHGs, $\mathrm{CO}_{2}$ is the most important, because it has the highest atmospheric concentration, highest emission rate, and substantially longer atmospheric lifetime (Kumar and Imam, 2013). Still, $\mathrm{CO}_{2}$ emissions will keep increasing because of the aerobic nature of agricultural practices (such as drainage) in peatlands (Beetz et al., 2013). The aerobic conditions also favour microbial activity and nitrogen mineralization in the peat profile above the water table (Hooijer et al., 2010). The directly proportional relationship between peatland utilization and $\mathrm{CO}_{2}$ emissions in temperate and boreal peatlands have been confirmed (Minkkinen et al., 2008). However, information on the relationship between tropical peatlands and $\mathrm{CO}_{2}$ emissions is still insufficient. Kumar and Imam (2013) noted that $\mathrm{CO}_{2}$ is produced by fossil fuel consumption, deforestation, and natural degradation of biomass sources, resulting in the oxidation of carbon compounds in marshes and forests. According to Hooijer et al. (2010), more studies are needed to complement the alreadyexisting data toward achieving a reliable estimate of $\mathrm{CO}_{2}$ emissions in drainage tropical peatlands. Huijnen et al. (2016) reported that in September and October 2015 where widespread forest and peatland fires burned over large parts of maritime SEA, a large amount of terrestrially-stored carbon was released into the atmosphere, primarily in the form of $\mathrm{CO}_{2}, \mathrm{CO}$, and $\mathrm{CH}_{4}$. Then, a mean emission rate of $11.3 \mathrm{Tg} \mathrm{CO}_{2}$ per day was recorded. The $\mathrm{CO}_{2}$ emissions from these fires exceeded the rate limit recommended by the European Union (EU28) (i.e., 8.9 $\mathrm{Tg} \mathrm{CO}_{2}$ per day).

\subsection{Nitrous oxide $\left(\mathrm{N}_{2} \mathrm{O}\right)$ emissions}

Another GHG with a long atmospheric residence time is $\mathrm{N}_{2} \mathrm{O}$. It is the fourth highest contributor to positive radiative forcing (Kumar and Imam, 2013; IPCC, 2007). Kumar and Imam (2013) also believed $\mathrm{N}_{2} \mathrm{O}$ contributes indirectly to environmental dilapidation such as corrosion. Primarily, $\mathrm{N}_{2} \mathrm{O}$ is produced by the burning of biomass and nitrogen-rich fuels (especially coal), decomposition of nitrogen fertilizers in the soil, livestock wastes, and of nitrate-contaminated groundwater. Still, continuous measurement, especially in agriculture areas with nitrogen inputs, is needed in peatlands to provide adequate information about $\mathrm{N}_{2} \mathrm{O}$ emissions (Hooijer et al., 2010; Couwenberg, 2009). The $\mathrm{N}_{2} \mathrm{O}$ emissions are higher in drained peatlands where fertilizers and manure are used (Beetz et al., 2013; Jassal et al., 2011).

\subsection{Methane $\left(\mathrm{CH}_{4}\right)$ emissions}

In terms of atmospheric concentration and emission frequency, $\mathrm{CH}_{4}$ is second to $\mathrm{CO}_{2}$, but 25 times more potent in global warming potential (Hooijer et al., 2010; Forster et al., 2007). $\mathrm{CH}_{4}$ has a significant influence on the earth's climate; it plays an important role 
in the formation of $\mathrm{O}_{3}$ and influences climate parameter (Kumar and Imam, 2013). In the agriculture sector, $\mathrm{CH}_{4}$ is produced from anaerobic degradation of organic matters in the rice field, natural wetlands, landfills, digestive tracts of a ruminant class of animals e.g., cattle, sheep, goats, deer, etc., production and utilization of oil and natural gas, and incomplete combustion of organics. $\mathrm{CH}_{4}$ emissions from peatlands (either undrain or drained) are modest in comparison with $\mathrm{CO}_{2}$ emissions (Hooijer et al., 2010; Couwenberg, 2009). Due to the significant role of $\mathrm{CH}_{4}$ in the net GHG tropical peatland balance, continuous measurement of $\mathrm{CH}_{4}$ flux over many years is needed (Hooijer et al., 2010). One of the activities for restoring drained peatlands is rewetting. However, rewetting peatlands to reach minimum water table would simultaneously increase $\mathrm{CH}_{4}$ emissions. This arises when the water level rises, the environment tends towards anaerobic condition, therefore, methanogenic bacteria would produce more $\mathrm{CH}_{4}$ (Beetz et al., 2013).

\subsection{Emission flux in peatlands}

Figure 7 shows peat carbon and GHG dynamics in a typical tropical peatland. There are limited data on $\mathrm{CO}_{2}$ emission fluxes in peatlands over the years. Also unavailable are subsidence data which provide information about the deposition of particulate and dissolved organic matters into rivers and canals (Hooijer et al., 2010). Continuous measurements of $\mathrm{CH}_{4}$ flux over many years would establish the role of $\mathrm{CH}_{4}$ in the net GHG balance in the tropical peatlands (Hooijer et al., 2010). An example of such established facts is this: the concentrations of $\mathrm{CH}_{4}$ in drained and undrained peatlands is moderate when compared to those of $\mathrm{CO}_{2}$ (Couwenberg, 2009; Hooijer et al., 2010). Further, more measurements on $\mathrm{N}_{2} \mathrm{O}$ are required, especially from agriculture-based emissions (Hooijer et al., 2010; Couwenberg, 2009).

GHG fluxes in SEA tropical peatlands influence water level, $\mathrm{pH}, \mathrm{C}: \mathrm{N}$, soil temperature, vegetation cover, and land use. As an example, the water level impacts peatland subsidence; it increases $0.9 \mathrm{~cm} \cdot \mathrm{a}^{-1}$ for every $10 \mathrm{~cm}$ drainage depth (Couwenberg, 2009). Although some studies have reported on some biases, there are still some uncertainties regarding flux measurement criteria (such as chamber configuration, flux derivation, measurement frequency and time). Therefore, adequate and effective measurement of $\mathrm{CO}_{2}$ fluxes should be continuous, or at least, consistent (Couwenberg, 2009).

With respect to $\mathrm{CH}_{4}$, Couwenberg (2009) found the flux balance in tropical peatlands is associated to water level, i.e., at the low water level of $\approx 20 \mathrm{~cm}, \mathrm{CH}_{4}$ flux values are generally negative. This means that the balancing value is gained by atmospheric uptake. However, at higher water levels, the values are usually higher and more variable as listed in Table 5. $\mathrm{N}_{2} \mathrm{O}$ emissions from fertilizer-improved agricultural tropical peat soils are sometimes higher than those from temperate peat soil (Couwenberg, 2009).

The assessment of the contribution of radiative forcing to global warming in tropical peatlands depends on the robust net annual estimation of $\mathrm{CO}_{2}, \mathrm{CH}_{4}$, and $\mathrm{N}_{2} \mathrm{O}$ emissions. 
However, reliable estimates are still unavailable for $\mathrm{CO}_{2}$ and $\mathrm{N}_{2} \mathrm{O}$ emissions from tropical peat soils (Couwenberg, 2009; Forster et al., 2007). By rewetting drained tropical peatlands, $\mathrm{CO}_{2}$ emission reduces, yet, the net carbon sequestration would not be reached. However, this does not apply to temperate and boreal peatlands because they have a low risk of increasing $\mathrm{N}_{2} \mathrm{O}$ emission. Besides, during heavy rainfall, there is excessive rewetting of fertilized drained areas, resulting in increased emission of $\mathrm{N}_{2} \mathrm{O}$, and ineffective reduction of $\mathrm{CO}_{2}$ emissions in these areas (Couwenberg, 2009).

To this end, adequate and reliable data of GHG emissions from peatland use and land use change are needed (Hergoualc'h and Verchot, 2014). Because $8 \%$ of global peatlands are in the tropics, there are $68 \%$ in the SEA which reserves about $6 \%$ of global peat carbon (Yu et al., 2010). However, between 1990 and 2000, peatland forest cover in Peninsula Malaysia, Sumatera, and Borneo decreased by $41 \%$ due to wildfires, land clearing, and cultivation in the drained peatlands, contributing to GHG emissions (Hergoualc'h and Verchot, 2014). So far, there is no confirmed quantitative estimation about atmospheric impacts because available data are limited and inconsistent (Frolking et al., 2011). The role of the tropical peatlands in global climate change in the future is still unclear, because of the yet-to-bedetermined relationship among GHG flux estimates, future land use, land-use change trajectories, and responses to effects of climate change on ecosystems, be they short term or long term (Hergoualc'h and Verchot, 2014; Frolking et al., 2011). Table 6 shows the emissions of three GHGs $\left(\mathrm{CO}_{2}, \mathrm{CH}_{4}\right.$ and $\left.\mathrm{N}_{2} \mathrm{O}\right)$ from seven land use categories (peat swamp forest $(\mathrm{F})$, degraded forest (Deg F), croplands and shrublands (C\&S), rice fields $(\mathrm{R})$, oil palm plantation (OP), golden wattle plantation (A), and sago palm plantation (S)), and their annual uptake in SEA.

Although, the net GHGs (mainly $\mathrm{CO}_{2}, \mathrm{CH}_{4}$ and $\mathrm{N}_{2} \mathrm{O}$ ) exchange between the atmosphere and land at some SEA peatlands have been studied, some strong pulse of GHGs (such as $\mathrm{N}_{2} \mathrm{O}$ and $\mathrm{CH}_{4}$ ) by wildfires (especially during dry seasons), and vegetation changes are still unaccounted for (Hergoualc'h and Verchot, 2014). Hergoualc'h and Verchot (2014) further argued that the estimation approach used by Reducing Emissions from Deforestation and forest Degradation (REDD+) to avoid $\mathrm{CO}_{2}$ emissions from peats on the basis of individual variables (such as depth of drainage) is incorrect. Moreover, alternative representatives of $\mathrm{N}$ value in soil can be used to assess soil GHG emissions. From their field study, soil GHG emissions should be considered along other environmental factors to achieve reliable results (Hergoualc'h and Verchot, 2014).

From quantitative research, more of $\mathrm{CH}_{4}$ is produced in restored peatlands than in degraded peatlands. It was established that restored peatlands act either as sinks or sources for GHGs. Further, the assessment and estimation of carbon and general GHG budget in peatlands have been compiled in Table 7 (Worrall et al., 2010). In relation to GHG emission fluxes in tropical peatlands, $\mathrm{CO}_{2}$ data are very limited, particularly with respect to drained and fireexposed areas. Due to the rarity of long-term $\mathrm{CO}_{2}$ flux data, there is a need for more studies 
on the relationship between peatland utilization and $\mathrm{CO}_{2}$ emissions, as well as improved estimation of $\mathrm{CO}_{2}$ emissions from drainage areas. Finally, such detailed research should be extended to $\mathrm{CH}_{4}$ and $\mathrm{N}_{2} \mathrm{O}$, especially in agriculture areas.

\section{Conclusion and recommendations}

Based on the reviewed literature on peatland GHG emissions, fluxes, and their global warming impact in SEA, we conclude the following:

- Classification, physicochemical properties, ecosystems, hydrology and water management, land use and land-use change, and GHG fluxes from peatlands are important to better management of peatland environment;

- Classification of peatlands could be based on geographical location, tides movement, water source, nutrients, levels of fertility and contents, or natural characteristics;

- For agricultural purposes, irrigation reduces the effect of toxic organics in peatlands. Soil liming improves soil physical condition and soil nutrients availability. Elaborate $\mathrm{C}$ and $\mathrm{N}$ cycles in tropical peatlands are needed to ascertain the influence of soil liming on peatlands. As a unique ecosystem, peatlands require some restoration, therefore, in-depth knowledge on peatland ecology is imperative.

- To develop peatlands appropriately, especially in the agricultural sectors and the water management system, a bridge between local wisdom and modern science is necessary to avoid culture offset.

- Canal blocking is a relatively clean method to restore water level in peatlands. However, rewetting peatlands would increase $\mathrm{CH}_{4}$ emissions.

- There are insufficient data on GHG emissions fluxes, especially on $\mathrm{CO}_{2}$ in drainage and fire areas, and on $\mathrm{N}_{2} \mathrm{O}$ fluxes in agriculture areas.

Consequently, we recommend that future research focus on the study of GHG fluxes in drained, post-fire, restored, and agricultural areas. The relationship between GHG emissions in tropical peatlands and global carbon content should be further investigated. The measurement of GHG fluxes in drained peatlands, post-fire tropical peatlands, and in restored peatlands, during dry and wet seasons, should be carried out. Where real-time analysis is not available or impossible, field samples should be collected for laboratory analysis. Finally, based on the data gathered, a mathematical model should be built on water management system toward restoring peatlands, as related to mitigation of GHG emissions.

\section{Acknowledgement}

This work has been supported by the Research England funding under the Global Challenge Research Fund (GCRF) programme for the CArE-Cities (Clean Air Engineering for Cities) project. Prashant Kumar acknowledges the funding support received through the European Union's Horizon 2020 research and innovation programme for OPERANDUM project under grant agreement No 776848.

\section{References}


Andriesse, J., 1988. Nature and management of tropical peat soils. Food \& Agriculture Org. Agus, F., Gunarso, P., Sahardjo, B.H., Harris, N., van Noordwijk, M., Killeen, T.J., 2013. Historical $\mathrm{CO}_{2}$ emissions from land use and land use change from the oil palm industry in Indonesia, Malaysia and Papua New Guinea. Reports from the Technical Panels of the $2^{\text {nd }}$ Greenhouse Gas; Working Group of the Roundtable on Sustainable Palm Oil, 65-88.

Anshari, G., Kershaw, P., Kaars, S.v.D., Jacobsen, G., 2004. Environmental change and peatland forest dynamics in the Lake Sentarum area, West Kalimantan, Indonesia. Journal of Quaternary Science 19, 637-655.

Batjes, N.H., 1996. Total carbon and nitrogen in the soils of the world. European journal of soil science 47, 151-163.

Beetz, S., Liebersbach, H., Glatzel, S., Jurasinski, G., Buczko, U., Höper, H., 2013. Effects of land use intensity on the full greenhouse gas balance in an Atlantic peat bog. Biogeosciences 10, 1067-1082.

Bourgeau-Chavez, L.L., Endres, S.L., Graham, J.A., Hribljan, Chimner, R.A., Lillieskov, E.A., Battaglia, M.J., 2018. Mapping peatlands in Boreal and Tropical ecoregions. Comprehensive Remote Sensing 6, 24-44.

Bragg, O., Tallis, J., 2001. The sensitivity of peat-covered upland landscapes. Catena 42, 345-360.

Brink, C., van Ierland, E., Hordijk, L., Kroeze, C., 2005. Cost-effective emission abatement in agriculture in the presence of interrelations: cases for the Netherlands and Europe. Ecological economics 53, 59-74.

Castro, K., Sanchez-Azofeifa, G.A., Rivard, B., 2003. Monitoring secondary tropical forests using space-borne data: implications for Central America. International Journal of Remote Sensing 24, 1853-1894.

Charman, D., 2002. Peatlands and environmental change. John Wiley \& Sons Ltd.

Chimner, R., Karberg, J., 2008. Long-term carbon accumulation in two tropical mountain peatlands, Andes Mountains, Ecuador. Mires and Peat 3, 1-10.

Chimner, R.A., Ewel, K.C., 2005. A tropical freshwater wetland: II. Production, decomposition, and peat formation. Wetlands Ecology and Management 13, 671-684.

Couwenberg, J., 2009. Methane emissions from peat soils (organic soils, histosols) facts, MRV-ability, emission factors. Wetlands International?

Fan, Z., Neff, J.C., Waldrop, M.P., Ballantyne, A.P., Turetsky, M.R., 2014. Transport of oxygen in soil pore-water systems: implications for modeling emissions of carbon dioxide and methane from peatlands. Biogeochemistry 121, 455-470.

FAO-UNESCO, 1990. Guidelines for soil description, 3rd ed. Food and Agriculture Organisation, Rome.

Forster, P., Ramaswamy, V., Artaxo, P., Berntsen, T., Betts, R., Fahey, D.W., Haywood, J., Lean, J., Lowe, D.C., Myhre, G., 2007. Changes in atmospheric constituents and in radiative forcing. Chapter 2, Climate Change 2007. The Physical Science Basis.

Frolking, S., Talbot, J., Jones, M.C., Treat, C.C., Kauffman, J.B., Tuittila, E.-S., Roulet, N., 2011. Peatlands in the Earth's 21st century climate system. Environmental Reviews 19, 371-396. 
Gorham, E., Lehman, C., Dyke, A., Clymo, D., Janssens, J., 2012. Long-term carbon sequestration in North American peatlands. Quaternary Science Reviews 58, 77-82.

Gurjar, B.R., Nagpure, A.S., Kumar, P., 2015. Gaseous emissions from agricultural activities and wetlands in national capital territory of Delhi. Ecological Engineering $75,123-127$.

Hartatik, W., Subiksa, I.G., Dariah, A., 2011. Chemistry and physical properties of peat soil. Report of Research and Development Centre of Republic of Indonesia, 45-56.

Hergoualc'h, K., Verchot, L., 2014. Greenhouse gas emission factors for land use and landuse change in SEA peatlands. Mitigation and Adaptation Strategies for Global Change 19, 789-807.

Holden, J., Chapman, P., Labadz, J., 2004. Artificial drainage of peatlands: hydrological and hydrochemical process and wetland restoration. Progress in Physical Geography 28, 95-123.

Hooijer, A., Page, S., Canadell, J., Silvius, M., Kwadijk, J., Wösten, H., Jauhiainen, J., 2010. Current and future $\mathrm{CO}_{2}$ emissions from drained peatlands in SEA.

Hooijer, A., Page, S., Navratil, P., Verimmen, R., van der Vat, M., Tansey, K., Konecny, K., Siegert, F., Ballhorn, U., Mawdsley, N., 2014. Carbon Emissions from Drained and Degraded Peatland in Indonesia and Emission Factors for Measurement, Reporting and Verification (MRV) of Peatland Greenhouse Gas Emissions. IAFCP, Jakarta, Indonesia.

Hoscilo, A., Page, S., Tansey, K., 2008. Development of post-fire vegetation in the tropical ecosystem of Central Kalimantan, Indonesia. Restoration of Tropical Peatlands, editors by: Henk Wosten, Jack Rieley and Susan Page. Restorpeat and International Peat Society, 2008, 148-153.

IPCC, 2001. Climate Change 2001: The Scientific Basis. Contribution of Working Group I to the Third Assessment Report of the Intergovernmental Panel on Climate Change [Houghton, J.T., Y. Ding, D.J. Griggs, M. Noguer, P.J. van der Linden, X. Dai, K. Maskell, and C.A. Johnson (eds.)]. Cambridge University Press, Cambridge, United Kingdom and New York, NY, USA, 881pp.

Huijnen, V., et al., 2016. Fire carbon emissions over maritime Southeast Asia in 2015 largest since 1997. Scientific Reports. 6, 26886.

IPCC, 2007. Summary for Policymakers. In: Climate Change 2007: The Physical Science Basis. Contribution of Working Group I to the Fourth Assessment Report of the Intergovernmental Panel on Climate Change [Solomon, S., D. Qin, M. Manning, Z. Chen, M. Marquis, K.B. Averyt, M.Tignor and H.L. Miller (eds.)]. Cambridge University Press, Cambridge, United Kingdom and New York, NY, USA.

Isaksen, I., Granier, C., Myhre, G., Berntsen, T., Dalsøren, S., Gauss, M., Klimont, Z., Benestad, R., Bousquet, P., Collins, W., 2009. Atmospheric composition change: climate-chemistry interactions. Atmospheric Environment 43, 5138-5192.

Ismail, Z., Yuan, C., Havmoller, P., 1999. Survey of fish diversity in peat swamp forest. Sustainable management of peat swamp forest in Peninsular Malaysia, 173-198.

Jassal, R.S., Black, T.A., Roy, R., Ethier, G., 2011. Effect of nitrogen fertilization on soil $\mathrm{CH} 4$ and N 2 O fluxes, and soil and bole respiration. Geoderma 162, 182-186. 
Jauhiainen, J., Takahashi, H., Heikkinen, J.E.P., Martikainen, P.J., Vasander, H., 2005. Carbon fluxes from a tropical peat swamp forest floor. Global Change Biology 11(10): 1788-1797.

Jayarathne, T., Stockwell, C. E., Gilbert, A. A., Daugherty, K., Cochrane, M. A., Ryan, K. C., Putra, E. I., Saharjo, B. H., Nurhayati, A. D., Albar, I., Yokelson, R. J., Stone, E. A., 2017. Chemical characterization of fine particulate matter emitted by peat fires in Central Kalimantan, Indonesia, during the 2015 El Niño. Atmos. Chem. Phys. Discuss. 2017, 1-47.

Johnson, G.A.L., 1963. The geology of Moor House: a national nature reserve in north-east Westmorland. HM Stationery Office.

Joosten, H., Couwenberg, J., 2009. Are emission reductions from peatland MRV-able? report, 14 pp. Wetlands International, Ede.

Josten, H., Clarke, D., 2002. Wise use of mires and peatlands: Background and principles including a framework for decision making. International Mire Conservation Group. International Peat Society, Jyväskylä 304.

Kononova, M., 1968. Transformations of organic matter and their relation to soil fertility. SOVIET SOIL SCIENCE-USSR, 1047.

Koplitz, N. S., Loretta, J. M., Miriam, E. M., Jonathan, J. B., Patrick, S. K., Tianjia, L., Melissa, P. S., Ruth, S. D., Daniel, J. J., Joel, S., Montira, P., Samuel, S. M., 2016. Public health impacts of the severe haze in Equatorial Asia in September-October 2015: demonstration of a new framework for informing fire management strategies to reduce downwind smoke exposure. Environmental Research Letters. 11, 094023.

Kumar, P., Imam, B., 2013. Footprints of air pollution and changing environment on the sustainability of built infrastructure. Science of the Total Environment 444, 85-101.

Limin, S., Jentha, Ermiasi, Y., 2007. History of the development of tropical peatland in Central Kalimantan, Indonesia. TROPICS 16, 291-301.

Lindsay, R., 1995. Bogs: The ecology, classification and conservation of ombrotrophic mires. Scottish Natural Heritage.

Lucas, R.M., Cronin, N., Moghaddam, M., Lee, A., Armston, J., Bunting, P., Witte, C., 2006. Integration of radar and Landsat-derived foliage projected cover for woody regrowth mapping, Queensland, Australia. Remote Sensing of Environment 100, 388406.

Marsden, K., Ebmeier, S., 2012. Peatlands and climate change. SPICe Briefing. The Scottish Parliament.

Marwanto, S., Agus, F., 2014. Is CO2 flux from oil palm plantations on peatland controlled by soil moisture and/or soil and air temperatures? Mitigation and Adaptation Strategies for Global Change 19, 809-819.

Melling, L., Tan, C. Y., Goh, K. J., \& Hatano, R., 2013. Soil microbial and root respirations from three ecosystems in tropical peatland of Sarawak, Malaysia. Journal of Oil Palm Research, 25(1), 44-57.

Melling, L, and Henson, I. E., 2011. Greenhouse gas exchange of tropical peatlands-a review. Oil Palm 23, 1087-1095. 
Minkkinen, K., Byrne, K.A., Trettin, C., 2008. Climate impacts of peatland forestry. Peatlands and Climate Change, 98-122.

Mona, B.N., 1984. Fuel peat in developing countries. Study Report for The World Bank, Dublin.

Nagano, T., Osawa, K., Ishida, T., Sakai, K., Vijarnsorn, P., Jongskul, A., Phetsuk, S., Waijaroen, S., Yamanoshita, T., Morisada, M., Kojima, K,m 2013. Subsidence and soil $\mathrm{CO}_{2}$ efflux in tropical peatland in southern Thailand under various water table and management conditions. Mires and Peat 11 (6), 1-20.

Norowi, M., Ismail, A., Jaya, J., Zulkifli, I., 2008. Spatio-temporal development of selected arthropod families on developing peatland ecosystem: their value as an agrienvironment indicator. Restoration of Tropical Peatlands, editors by: Henk Wosten, Jack Rieley and Susan Page. Restorpeat and International Peat Society, 2008, 160164.

Nusantara, R.W., Sudarmadji, Djohan, T.S., Haryono, E., 2014. Soil emissions of CO2 due to land use change of peat swamp forest at West Kalimantan. Jurnal Manusia dan Lingkungan 21, 268-276.

Othman, J., Sahani, M., Mahmud, M., Sheikh Ahmad, M. K., 2014. Transboundary smoke haze pollution in Malaysia: Inpatient health impacts and economic valuation. Environmental Pollution. 189, 194-201.

Page, S., Hooijer A., Rieley, J., Banks, C., Hoscilo, A., 2012. The tropical peat swamps of Southeast Asia. Biotic Evolution and Environmental Change in Southeast Asia, 406433.

Page, S.E., Rieley, J.O., Banls, C.J., 2011. Global and regional importance of the tropical peatland carbon pool. Global Change Biology 17 (2), 798-818.

Page, S., Graham, L., Hoscilo, A., Limin, S., 2008. Vegetation restoration on degraded tropical peatlands: opportunities and barriers. Restoration of Tropical Peatlands, editors by: Henk Wosten, Jack Rieley and Susan Page. Restorpeat and International Peat Society, 2008, 64-68.

Page, S., Siegert, F., Rieley, J., Boehm, H.-D.V., Jaya, A., Limin, S., 2002. The amount of carbon released from peat and forest fires in Indonesia during 1997. Nature 420, 6164.

Page, S., Rieley, J., Shotyk, Ø., Weiss, D., 1999. Interdependence of peat and vegetation in a tropical peat swamp forest. Philosophical Transactions of the Royal Society B: Biological Sciences 354, 1885-1897.

Pandjaitan, N.H., Hardjoamidjojo, S., 2008. Review of peatlands physical properties related to drainage in agriculture. Buletin Keteknikan Pertanian 3, 87-96.

Polak, B., 1949. The Rawa Lakbok (South Priangan, Java): investigation into the composition of an eutrophic topogenous bog. Cont. Gen. Agr. Res. Sta. No.8, Bogor, Indonesia.

Rieley, J., Notohadiprawiro, T., Setiadi, B., Limin, S., 2008. Restoration of tropical peatland in Indonesia: why, where and how? Restoration of Tropical Peatlands, editors by: Henk Wosten, Jack Rieley and Susan Page. Restorpeat and International Peat Society, 2008, 20-28. 
Ritzema, H., 2008. The role of drainage in the wise use of tropical peatlands. Restoration of Tropical Peatlands, editors by: Henk Wosten, Jack Rieley and Susan Page. Restorpeat and International Peat Society, 2008, 78-87.

Rydin, H., Jeglum, J.K., 2013. The Biology of Peatlands, 2e. Oxford University Press.

Setyanto, P., Sopiawati, T., Adriani, T.A., Pramono, A., Hervani, A., Wahyuni, S., Wihardjaka, A., 2014. Greenhouse gases emissions from peat land use and ameliorant application: synthesis of five research sites. Research of Agricultural Environment Agency, Ministry of Agriculture, Republic of Indonesia, 45-61.

Stockwell, C. E., Jayarathne, T., Cochrane, M. A., Ryan, K. C., Putra, E. I., Saharjo, B. H., Nurhayati, A. D., Albar, I., Blake, D. R., Simpson, I. J., Stone, E. A., Yokelson, R. J., 2016. Field measurements of trace gases and aerosols emitted by peat fires in Central Kalimantan, Indonesia, during the 2015 El Niño. Atmos. Chem. Phys. 16, 11711-11732.

Sukarman, Suparto, Mamat, 2012. Managing sustainable peatland. Proceeding in National Seminar, Bogor Indonesia 4 May 2012. Agricultural Research and Development Agency. The Ministry of Agriculture Republic of Indonesia., 96-111.

Suzuki, S., Ishida, T., Nagano, T., Waijaroen, S., 1999. Influences of deforestation on carbon balance in a natural tropical peat swamp forest in Thailand. Environmental COntrol in Biology 37(2), 115-128.

Tarnocai, C., Canadell, J., Schuur, E., Kuhry, P., Mazhitova, G., Zimov, S., 2009. Soil organic carbon pools in the northern circumpolar permafrost region. Global Biogeochemical Cycles 23.

UNEP/GEF, 2008. Assessment on peatlands, biodiversity and climate change. Main report. United Nations Environment Programme/Global Environment Facility.

Unger, N., 2012. Global climate forcing by criteria air pollutants. Annual Review of Environment and Resources 37, 1-24.

van Noordwijk, M., Agus, F., Dewi, S., Purnomo, H., 2014. Reducing emissions from land use in Indonesia: motivation, policy instruments and expected funding streams. Mitigation and Adaptation Strategies for Global Change 19, 677-692.

Velasco, E., and Rastan, S. 2015. Air quality in Singapore during the 2013 smoke-haze episode over the Strait of Malacca: Lessons learned. Sustainable Cities and Society, 17, 122-131.

Widjaja-Adhi, I., 1988. Physical and chemical characteristic of peat soil of Indonesia. Ind. Agric. Res. Dev. J 10, 59-64.

Worrall, F., Chapman, P., Holden, J., Evans, C., Artz, R., Smith, P., Grayson, R., 2010. A review of current evidence on carbon fluxes and greenhouse gas emissions from UK peatlands. Join Nature Conservation Commitee (JNCC) Report No. 442, Peterborough, 2011.

Wösten, J., Clymans, E., Page, S., Rieley, J., Limin, S., 2008. Peat-water interrelationships in a tropical peatland ecosystem in Southeast Asia. Catena 73, 212-224.

Yang, G., Peng, C., Chen, H., Dong, F., Wu, N., Yang, Y., et al., 2017. Qinghai-Tibetan Plateau peatland sustainable utilization under anthropogenic disturbancees and climate change. Ecosystem Health and Sustainability 3(3), 1263-1272. 
Yokelson, R. J., R. Susott, D. E. Ward, J. Reardon, and D. W. T. Griffith (1997), Emissions from smoldering combustion of biomass measured by open-path Fourier transform infrared spectroscopy, J. Geophys. Res., 102, 18,865-18,877, doi:10.1029/97JD00852.

Yu, Z., Loisel, J., Brosseau, D.P., Beilman, D.W., Hunt, S.J., 2010. Global peatland dynamics since the Last Glacial Maximum. Geophysical Research Letters 37.

Zinck, J.A., Huber, O., Schargel, R., 2011. Peatlands of the Western Guayana Highlands, Venezuela. Springer. 


\section{List of Figures}
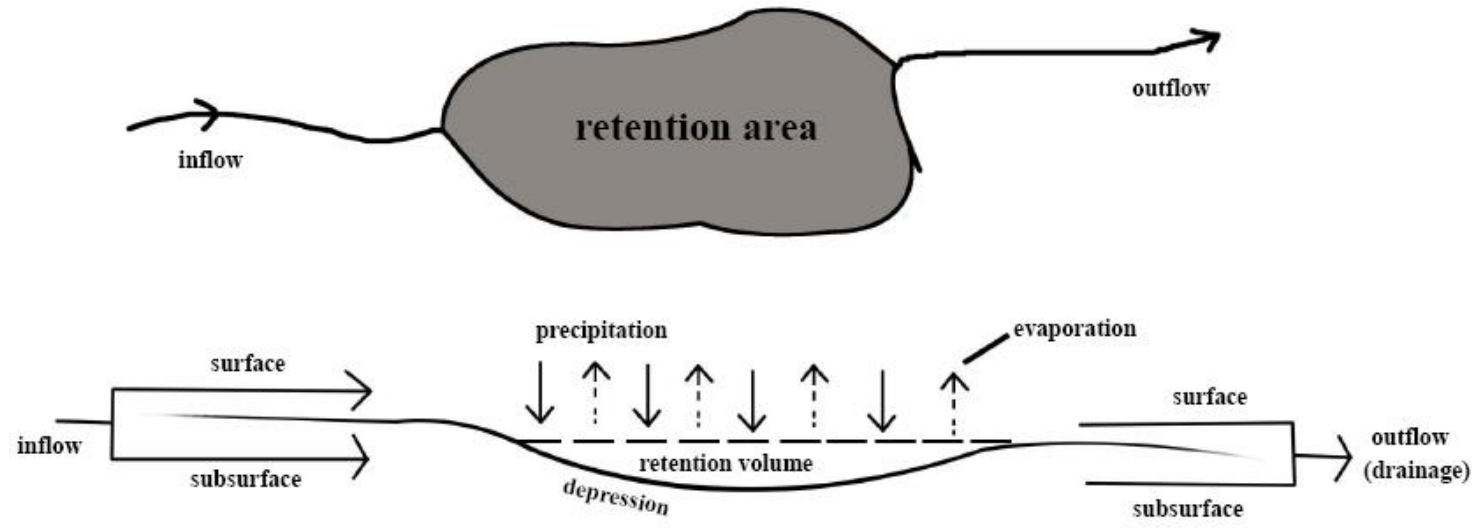

Figure 1. A generalized scheme for the formation of peats (adapted from Andriesse, 1988).
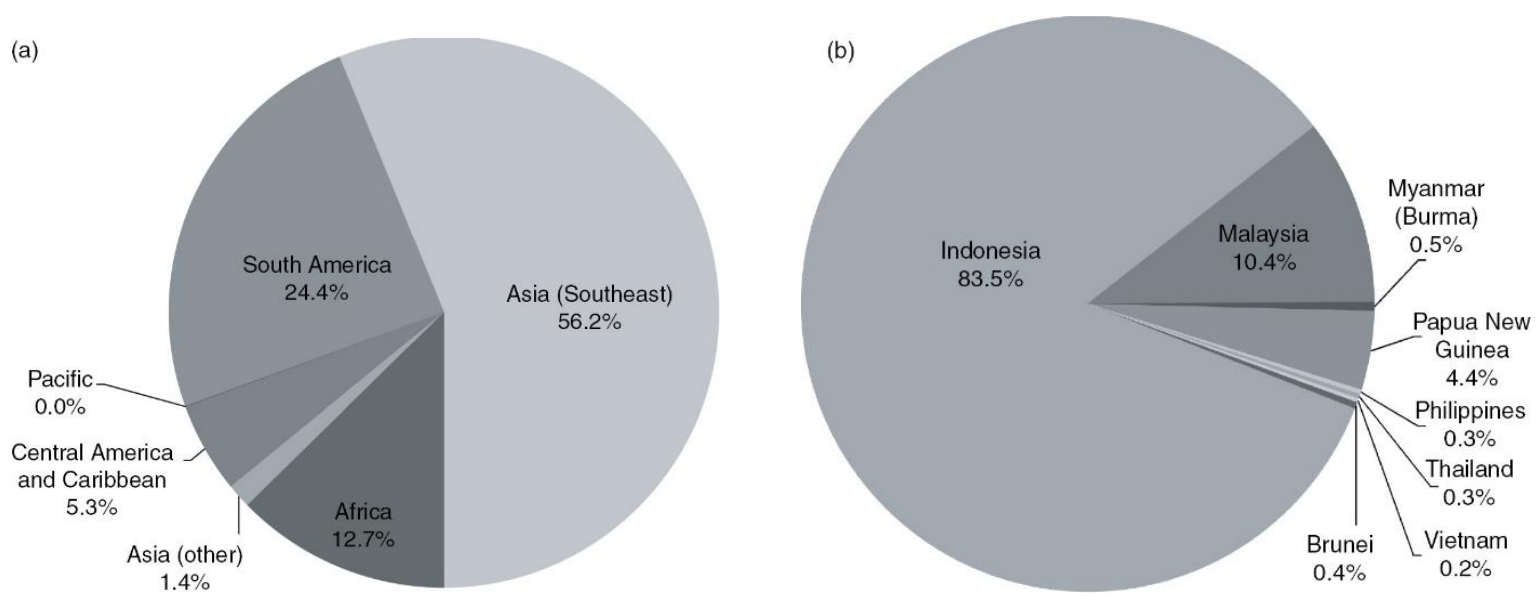

Figure 2. Percentage distribution of (a) global and (b) Southeast Asia (SEA) peatlands (Page et al., 2012; Zinck et al., 2011; Andriesse, 1988; Mona, 1984). 


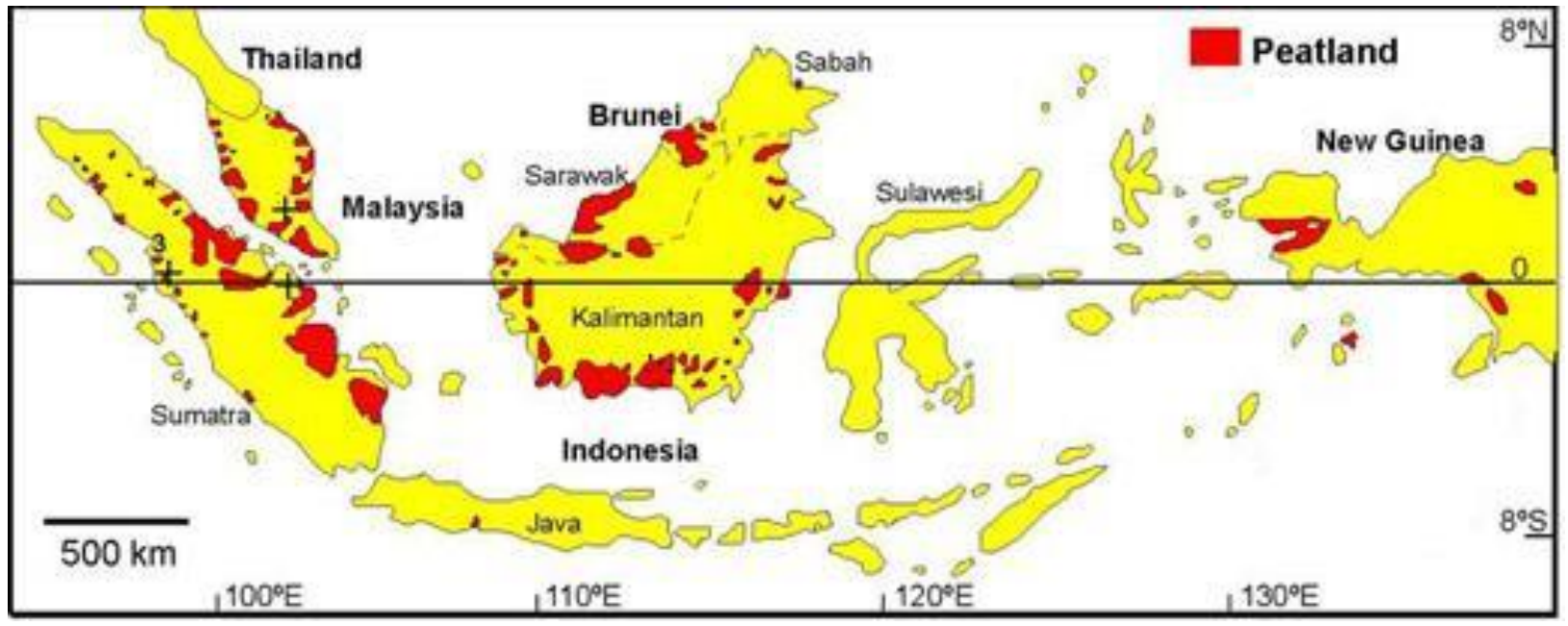

Figure 3. Major peatland areas (in red) in Peninsular Malaysia, Sabah and Sarawak,

Sumatra, Borneo and Papua (adapted from Page et al., 2011).

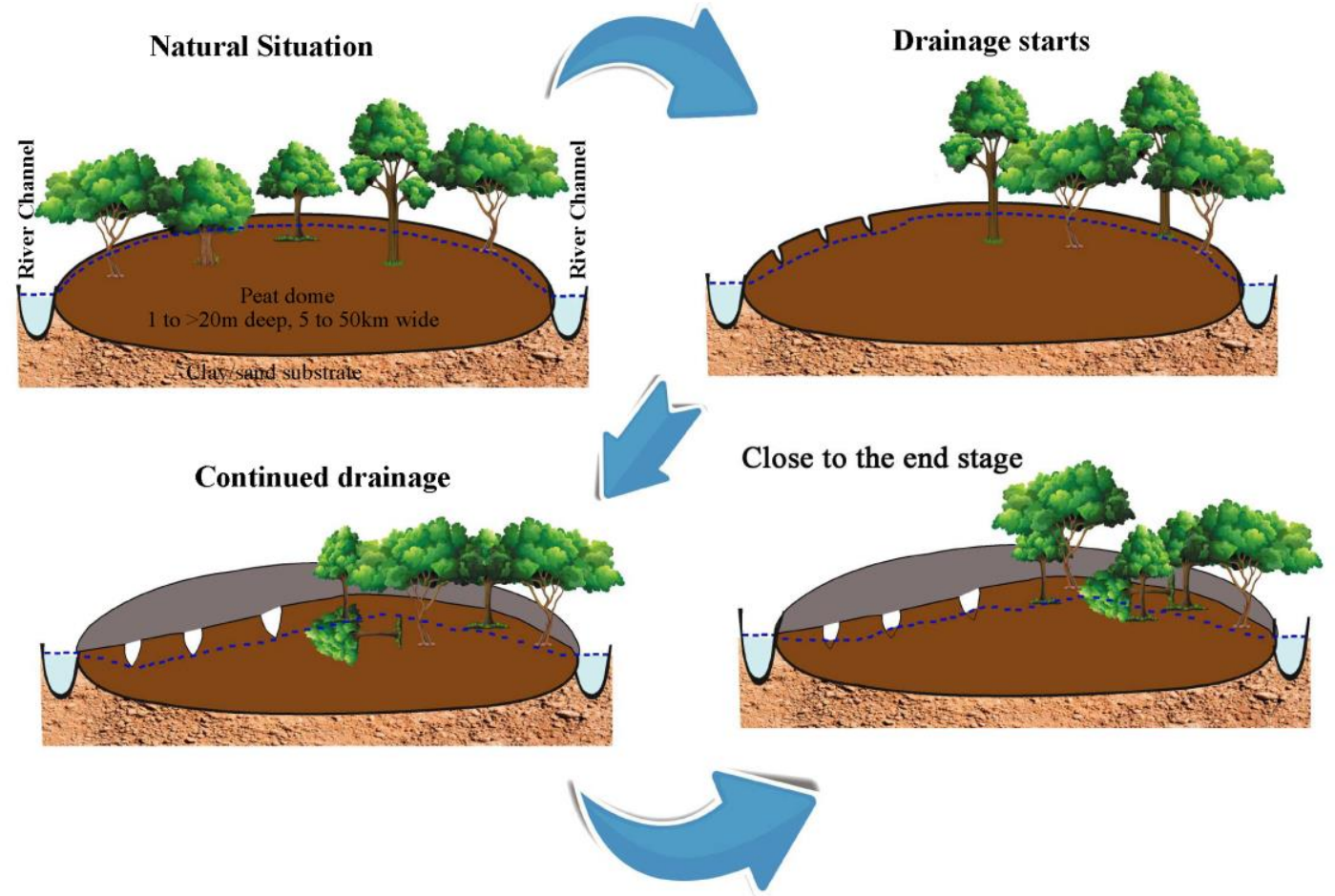

Figure 4. A scheme showing the progressive effect of drainage on peatlands. 
Kumar et al., 2019. Towards an improved understanding of greenhouse gas emissions and fluxes in tropical peatlands of Southeast Asia. Published in journal, Sustainable Cities and Society.

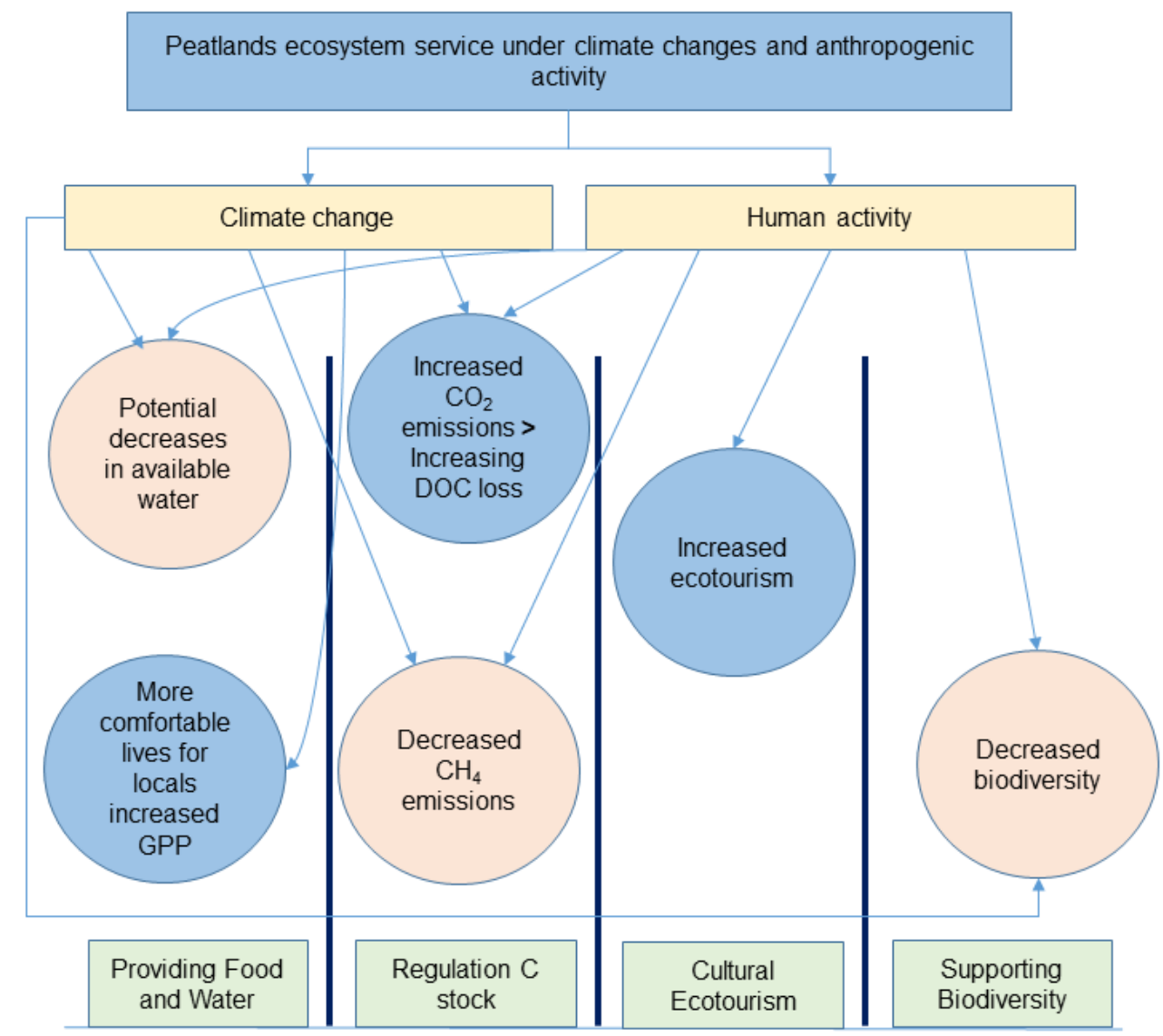

Figure 5. A typical peatland ecosystem services under climate change and anthropogenic activities (adapted from Yang et al., 2017). 
Kumar et al., 2019. Towards an improved understanding of greenhouse gas emissions and fluxes in tropical peatlands of Southeast Asia. Published in journal, Sustainable Cities and Society.

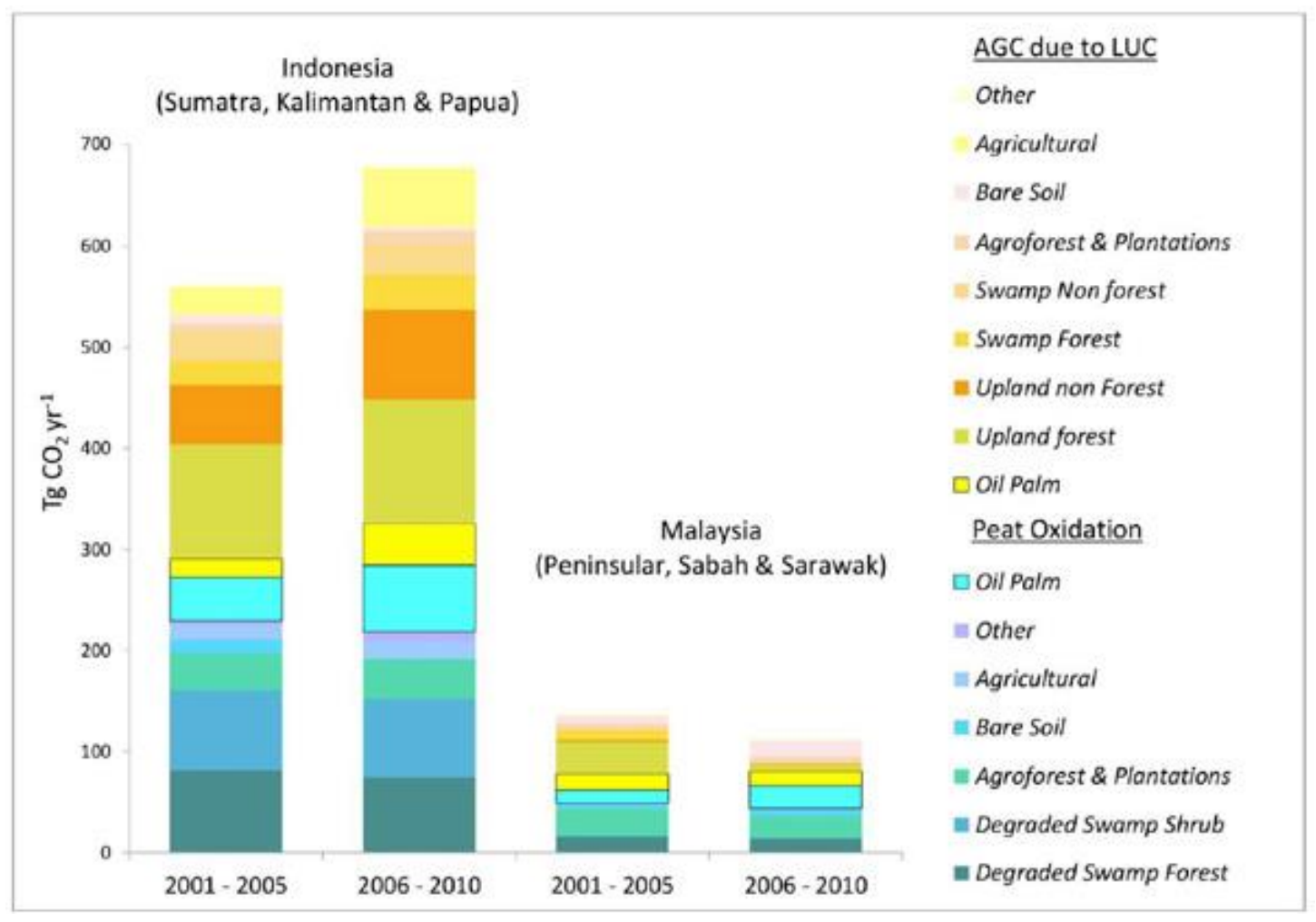

Figure 6. Estimated mean annual emissions stratified by the source of emissions for aboveground carbon due to land use change and the oxidation of peat soils from drainage and land conversion (Agus et al., 2013). 


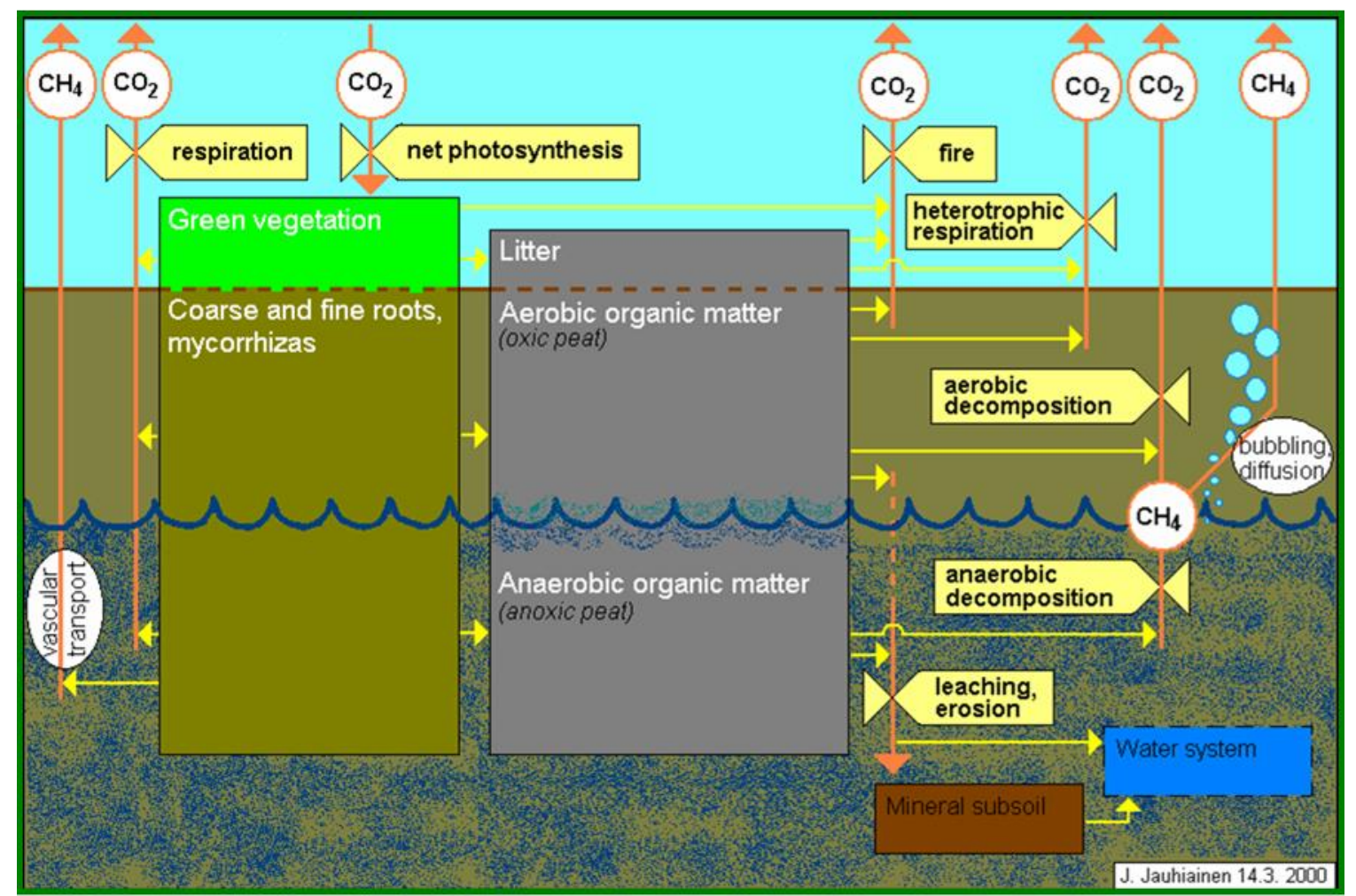

Figure 7. Peat carbon and greenhouse gas dynamics showing major peat carbon stocks, pathways, and processes in tropical peatlands (taken from Janhiainen et al., 2002). 
Table 1. Types of peatlands based on natural characteristics (Pandjaitan and Hardjoamidjojo, 2008; Andriesse, 1988).

\begin{tabular}{|c|c|}
\hline Nature characteristics & Type of peatlands \\
\hline Topography and geomorphology & $\begin{array}{l}\text { Based on the landscape: } \\
\text { - Low moor peat } \\
\text { - Transitional moor peat } \\
\text { - High moor peat }\end{array}$ \\
\hline Vegetation cover & Usually associated with management purposes \\
\hline Origin vegetation & $\begin{array}{l}\text { Based on the peatland-forming vegetation: } \\
\text { - Moss peat } \\
\text { - Saw-grass peat } \\
\text { - Cyperaceae peat } \\
\text { - Forest and woody peat }\end{array}$ \\
\hline Chemical properties & $\begin{array}{l}\text { Based on the level of fertility: } \\
\text { - Eutrophic } \\
\text { - Mesotrophic } \\
\text { - Oligotrophic }\end{array}$ \\
\hline Physical properties & $\begin{array}{l}\text { Based on the extent of decomposition: } \\
\text { - } \text { Fibric (if organic content is }>2 / 3 \text { ) } \\
\text { - Hemic (if organic content is } \leq 2 / 3 \text { but } \geq 1 / 3 \text { ) } \\
\text { - } \text { Sapric (if organic content is }<1 / 3 \text { ) }\end{array}$ \\
\hline Genesis process & $\begin{array}{l}\text { Based on the climate when the peatlands were formed: } \\
\text { - Tropical and subtropical peatlands } \\
\text { - Boreal and temperate peatlands }\end{array}$ \\
\hline
\end{tabular}

Table 2. The water content of peatlands at different decomposition level (Hartatik et al., 2011)

\begin{tabular}{ll}
\hline Level of peatland decomposition & $\mathbf{\%} \mathbf{H}_{\mathbf{2}} \mathbf{O}$ content (in oven-dried peat) \\
\hline Fibric & 850 to $3000 \%$ \\
Hemic & 450 to $850 \%$ \\
Sapric & $<450 \%$ \\
\hline
\end{tabular}


Table 3. Type of peat based on nutrients availability (Zinck et al., 2011).

\begin{tabular}{lll}
\hline Peat type & Nutrients availability & Nutrient Source \\
\hline Eutrophic & Rich & Overland flow or river flooding \\
Mesotrophic & Moderately rich & Low molecular weight organic acids \\
Oligotrophic & Poor & Rainwater only \\
\hline
\end{tabular}

Table 4. Previous studies on chemical properties of Indonesian peatlands (Hartatik et al., 2011).

\begin{tabular}{|c|c|}
\hline Author & Result/Found \\
\hline $\begin{array}{l}\text { Stevenson (1994); Tan } \\
\text { (1993) }\end{array}$ & $\begin{array}{l}\text { - Organic content is }<95 \% \text {; the rest are inorganics } \\
\text { - Organic fraction consists of } 10 \% \text { to } 20 \% \text { humic compounds } \\
\text { (humic acid, humin and himatomelanat) } \\
\text { - Non-humic compounds found: lignin, cellulose, hemicellulose, } \\
\text { wax, tannins, resins, suberin, and a small amount of protein. } \\
\text { - Chemical characteristics depend on mineral content, thickness, } \\
\text { type of peat plant and peat substratum (base material), and } \\
\text { degree of peat composition. }\end{array}$ \\
\hline $\begin{array}{l}\text { Andriesse (1974); Miller } \\
\text { and Donahue (1990) }\end{array}$ & $\begin{array}{l}\text { - Peatland is mostly acidic with } \mathrm{pH}<4.0 \\
\text { - Due to the high acidity, content organic acids found are humic } \\
\text { acid and fulvic acid }\end{array}$ \\
\hline $\begin{array}{l}\text { Driessen (1978); Driessen } \\
\text { and Suhardjo (1976) }\end{array}$ & $\begin{array}{l}\text { - Peats are generally formed from timber, with lignin content } \\
\text { higher than those of peat soils in temperate regions }\end{array}$ \\
\hline Radjagukguk (1997) & $\begin{array}{l}\text { - Ombrogen is dominant, especially in inland peats which are } \\
\text { thick and of low nutrients } \\
\text { - Peats are of an oligotrophic level } \\
\text { - Coastal peats are generally topogen and classified as } \\
\text { eutrophic; rich in } \mathrm{Ca}, \mathrm{Mg} \text {, and } \mathrm{K}\end{array}$ \\
\hline $\begin{array}{l}\text { Driessen (1978); Andriesse } \\
\text { (1974) }\end{array}$ & $\begin{array}{l}\text { - Cation exchange capacity (CEC) of ombrogen peat in } \\
\text { Indonesia is largely determined by the fraction of lignin and } \\
\text { humic compounds }\end{array}$ \\
\hline
\end{tabular}


Table 5. Methane fluxes balance related to land-use (Couwenberg, 2009).

\begin{tabular}{llll}
\hline Land Use & $\begin{array}{l}\mathbf{C H}_{\mathbf{4}} \text { flux } \\
\left(\mathbf{m g C H} \mathbf{~ m}^{-\mathbf{1}} \mathbf{h}^{-\mathbf{1}}\right)\end{array}$ & Complement & Reference \\
\hline Paddy fields & $3.5-14$ & $\begin{array}{l}\text { Without water level } \\
\text { indicated }\end{array}$ & Hadi et al. (2002) \\
\hline Rice plant & Up to 35 & Paddies on peaty alluvium & $\begin{array}{l}\text { Furukawa et al. } \\
(2005)\end{array}$ \\
\hline $\begin{array}{l}\text { Waterlog } \\
\text { previously } \\
\text { drained and } \\
\text { abandoned } \\
\text { freshwater } \\
\text { swamp }\end{array}$ & 12.5 & Attributed to ebullition & Ueda et al. (2000) \\
\hline \begin{tabular}{l} 
Cassava field \\
\hline
\end{tabular} & 16.8 & $\begin{array}{l}\text { Biochar lowers } \mathrm{CH}_{4} \\
\text { production }\end{array}$ & $\begin{array}{l}\text { Takakai et al. } \\
\text { (2005) }\end{array}$ \\
\hline
\end{tabular}

Table 6. $\mathrm{CO}_{2}, \mathrm{CH}_{4}$ and $\mathrm{N}_{2} \mathrm{O}$ fluxes (mean $\pm \mathrm{SE}\left(\mathrm{gm}^{-2} \mathrm{~d}^{-1}\right)$ ) by land use types (Hergoualc'h and Verchot, 2014).

\begin{tabular}{clllllll}
\hline GHGs & \multicolumn{7}{c}{ Land Use Types } \\
\cline { 2 - 8 } & $\mathrm{F}$ & $\mathrm{Deg} \mathrm{F}$ & $\mathrm{C} \& \mathrm{~S}$ & $\mathrm{R}$ & $\mathrm{OP}$ & $\mathrm{A}$ & $\mathrm{S}$ \\
\hline $\mathrm{CO}_{2}$ & $-5.3 \pm 5.8$ & $19.4 \pm 9.4$ & $41.0 \pm 6.7$ & $25.6 \pm 11.5$ & $29.9 \pm 10.6$ & $71.8 \pm 12.7$ & $5.2 \pm 5.1$ \\
$\mathrm{CH}_{4}$ & $2.7 \pm 0.9$ & $0.4 \pm 0.2$ & $0.5 \pm 0.5$ & $10.3 \pm 5.8$ & 0.0 & $0.2 \pm 0.3$ & $1.9 \pm 1.4$ \\
$\mathrm{~N} 2 \mathrm{O}$ & $1.2 \pm 0.9$ & $1.1 \pm 0.5$ & $2.3 \pm 1.2$ & $0.2 \pm 0.2$ & 0.5 & & $1.5 \pm 0.2$ \\
$\mathrm{Net}$ & $-1.3 \pm 5.9$ & $20.9 \pm 9.4$ & $43.8 \pm 6.8$ & $36.1 \pm 12.9$ & $30.4 \pm 10.6$ & $72.0 \pm 12.8$ & $8.6 \pm 5.3$ \\
$\mathrm{GHG}$ & $(-396,204,91)$ & $(93,2,5)$ & $(94,1,5)$ & $(71,29,1)$ & $(98,0,2)$ & $(100,0,-)$ & $(60,22,17)$ \\
\hline
\end{tabular}


Table 7. Estimation methods for carbon and GHG budgets of peatlands (Worrall et al., 2010).

\begin{tabular}{ll}
\hline Methods & Approach and Result \\
\hline $\begin{array}{l}\text { Dating of peat } \\
\text { accumulation }\end{array}$ & $\begin{array}{l}\text { To give a rate of C accumulation } \\
\text { in peatland systems }\end{array}$
\end{tabular}

\section{Characteristics}

- Cannot be used to estimate C losses in degraded peatlands unless an obvious eroded surface is present

- Usually over long periods: 10 to 100 years

- No indication of the temporal variation in $\mathrm{C}$ accumulation for shorter periods

- Unsuitable for understanding the impact of land management change in $\mathrm{C}$ budget

- Only used to provide baseline information, to indicate the typical function of active, relatively unmanaged peatlands

\begin{tabular}{|c|c|}
\hline $\begin{array}{l}\text { Measuring } \\
\text { accumulation } \\
\text { or loss of peat } \\
\text { material }\end{array}$ & $\begin{array}{l}\text { - To observe if peat mass loss } \\
\text { using erosion pins or transect } \\
\text { - To observe changes in peat } \\
\text { surface elevation over time b } \\
\text { using artificial structures } \\
\text { - To estimate loss by using dat } \\
\text { photographic evidence }\end{array}$ \\
\hline $\begin{array}{l}\text { Measuring C } \\
\text { fluxes between } \\
\text { the ecosystem } \\
\text { and the } \\
\text { atmosphere }\end{array}$ & $\begin{array}{l}\text { To calculate a present day } \mathrm{C} \\
\text { budget }\end{array}$ \\
\hline
\end{tabular}

- Both approaches are based on measuring peat surface and rely on assuming the bulk density of the material lost

- It may fail in the estimation of peat compression

- Cannot estimate the impact of methane flux

- Cannot give an accurate classification of peat loss between gaseous and fluvial pathways

- Based on measuring/estimating fluxes $\mathrm{C}$ and GHGs with the atmosphere and C fluxes to fluvial system

- Can capture all types of peat $\mathrm{C}$ and GHG fluxes with limitation of measurement and experimental design

- Needs regular onsite measurement to fully capture temporal variability in the system

- It is harder to integrate over long period 


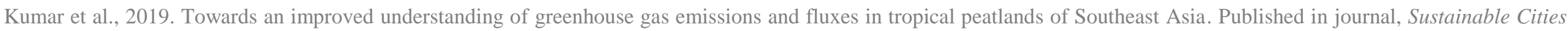
and Society. 